\title{
Reply to: Increased prevalence of Sarcoidosis in Ireland
}

\author{
S. C. Donnelly $\cdot$ M. Walters
}

Received: 26 April 2012/Accepted: 21 May 2012/Published online: 3 June 2012

(C) Royal Academy of Medicine in Ireland 2012

To the Editor,

Historically, published work has defined the prevalence of Sarcoidosis in Ireland as between 10 and 33 cases/100,000 $[1,2]$. Clinicians in Ireland believe this to be an underestimation. Consequently, we sought to define the number of active cases of Sarcoidosis in a defined geographical area, namely County Offaly, in 2011.

The population of this area is 76,806 (Irish Census, 2011). Approval was obtained from the Midlands Medical Ethics Committee. Analysis of medical records identified 65 cases giving a prevalence of 85 cases $/ 100,000$. Thirtythree percent presented with Erythema Nodosum (EN). Of the non-EN group, a tissue diagnosis was obtained in $80 \%$ of cases. We have identified a prevalence for Sarcoidosis of
85 cases/100,000 in County Offaly, Ireland. While there may be inter-regional variation within Ireland [2], it suggests that up to 5,400 cases of Sarcoidosis potentially exist within Ireland.

\section{References}

1. Bauer HJ, Lofgren S (1964) International study of pulmonary Sarcoidosis in mass chest radiography. Acta Med Scand 425(suppl):103-105

2. Nicholson TT, Plant BJ, Henry MT, Bredin CP (2010) Sarcoidosis in Ireland: regional differences in prevalence and mortality from 1996-2005. Sarcoidosis Vasc Diffuse Lung Dis 27:111-120
S. C. Donnelly $(\bowtie)$

St Vincent's University Hospital,

Dublin 4, Ireland

e-mail: seamas.donnelly@ucd.ie

\section{Walters}

Irish Sarcoidosis Support Group, ISARC, Gurtacur,

Mount Bolus, Tullamore, Co. Offaly, Ireland

URL: http://www.isarc.ie 